\title{
Characterization of PM-Bound Heavy Metal at Road Environment in Tianjin: Size Distribution and Source Identification
}

\author{
Qijun Zhang, Hongjun Mao *, Yanjie Zhang and Lin Wu
}

Citation: Zhang, Q.; Mao, H.; Zhang,

Y.; Wu, L. Characterization of

PM-Bound Heavy Metal at Road

Environment in Tianjin: Size

Distribution and Source Identification.

Atmosphere 2021, 12, 1130. https://

doi.org/10.3390/atmos12091130

Academic Editors: Chris G. Tzanis and Artur Badyda

Received: 3 August 2021

Accepted: 31 August 2021

Published: 2 September 2021

Publisher's Note: MDPI stays neutral with regard to jurisdictional claims in published maps and institutional affiliations.

Copyright: (c) 2021 by the authors. Licensee MDPI, Basel, Switzerland. This article is an open access article distributed under the terms and conditions of the Creative Commons Attribution (CC BY) license (https:/ / creativecommons.org/licenses/by/ $4.0 /)$.
Tianjin Key Laboratory of Urban Transport Emission Research, College of Environmental Science and Engineering, Nankai University, Tianjin 300071, China; zhangqijun@nankai.edu.cn (Q.Z.); yiying5120@126.com (Y.Z.); wlnankai@sohu.com (L.W.)

* Correspondence: hongjunm@sohu.com; Tel.: +86-22-23504912

\begin{abstract}
To determine the size distribution and source identification of PM-bound heavy metals in roadside environments, four different particle size $(<0.2 \mu \mathrm{m}, 0.2-0.5 \mu \mathrm{m}, 0.5-1.0 \mu \mathrm{m}$ and $1.0-2.5 \mu \mathrm{m})$ samples were collected and analyzed from four different types of roads during the summer of 2015 in Tianjin. The results showed that the concentrations of PM-bound heavy metal from the roadside environment sampling sites were $597 \pm 251 \mathrm{ng} / \mathrm{m}^{3}$ (BD), $546 \pm 316 \mathrm{ng} / \mathrm{m}^{3}$ (FK), $518 \pm 310 \mathrm{ng} / \mathrm{m}^{3}$ (JY) and $640 \pm 237 \mathrm{ng} / \mathrm{m}^{3}(\mathrm{WH})$. There were differences in the concentrations of the heavy metal elements in the four different particle size fractions. The concentrations of $\mathrm{Cu}, \mathrm{Zn}, \mathrm{Cd}, \mathrm{Sn}$ and $\mathrm{Pb}$ were the highest in the larger particle size fraction $(0.5-2.5 \mu \mathrm{m}) . \mathrm{Cd}, \mathrm{Cu}, \mathrm{Zn}$ and $\mathrm{Pb}$ were the elements that indicated emissions from tire wear and brake pad wear. The concentrations of $\mathrm{Cr}$, $\mathrm{Co}$ and $\mathrm{Ni}$ were the highest in the smallest particle size fraction $(<0.5 \mu \mathrm{m})$, indicating that motor vehicle exhaust was their main source. The correlation analysis results showed that there are differences in the concentration, distribution and correlation of different PM-bound heavy metals in different particle size fractions. The PCA results show that the accumulative interpretation variances of $\mathrm{PM}_{0.2}, \mathrm{PM}_{0.2-0.5}, \mathrm{PM}_{0.5-1.0}$ and $\mathrm{PM}_{1.0-2.5}$ reached $80.29 \%, 79.56 \%, 79.57 \%$ and $71.42 \%$, respectively. Vehicle exhaust was the primary source of PM-bound heavy metal collected from the roadside sampling sites, while brake pad wear and tire wear were the second most common sources of the heavy metal.
\end{abstract}

Keywords: roadside environment; PM-bound heavy metal; size distribution; source identification

\section{Introduction}

Serious air pollution and smog are frequently observed in the Beijing-Tianjin-Hebei region. According to the latest source apportionment results released by the Ministry of Ecology and Environment (MEE), traffic emissions, industrial manufacturing, coal combustion and dust are the main sources of particulate matter (PM) in the ambient air of most cities in China. Among these sources, traffic has become the primary source of air pollution in Beijing, Guangzhou and Shenzhen. The contribution of traffic emissions to urban atmospheric environmental particulate matter is $45 \%$ in Beijing, $29.2 \%$ in Shanghai, $16.3 \%$ in Guangzhou and 20\% in Tianjin [1]. As industrial pollution sources gradually migrate to the suburbs, the contribution of traffic emissions in the central urban areas becomes higher in some large and medium-sized cities. This study focuses on the emission characteristics of PM-bound heavy metals in the road environment, which have been significantly contributed to by traffic emissions in city.

Some researchers are studying vehicle emission factors and compiling an emissions inventory [2-6]. At the same time, a small number of researchers have studied the size-resolved distribution and the source identification of PM-bound heavy metals. Sizeresolved distribution is one of the basic parameters used to characterize particulate matter and can be used to characterize the migration and deposition of particulate matter [7]. 
Domestic and foreign researchers have studied the size-resolved distribution of heavy metals in particles from traffic sources. Mery Malandrino [8] carried out an ambient aerosol sampling to determine the characteristics of metals in different size fractions, which were collected from the center of the city of Turin in 2011. The results showed that elements such as $\mathrm{As}, \mathrm{Co}, \mathrm{Pb}$ and $\mathrm{V}$ were mainly associated with fine particles $\left(\mathrm{PM}_{2.5}\right)$, while $\mathrm{Fe}, \mathrm{Mn}, \mathrm{Mo}$, $\mathrm{Cd}, \mathrm{Cr}, \mathrm{Cu}$ and $\mathrm{Sn}$ were mainly associated with coarse particles (PM10). Cheng Yan et al. [9] collected $\mathrm{PM}_{10}$ and $\mathrm{PM}_{2.5}$ samples from roadsides in Hong Kong in 2004, and the distinct differences between the chemical characteristics and sources of the $\mathrm{PM}_{2.5}$ and $\mathrm{PM}_{2.5-10}$ samples were investigated. These studies were both focused on the PM-bound heavy metal in $\mathrm{PM}_{2.5}$ and $\mathrm{PM}_{10}$ from traffic emissions, and there were few related studies on particle sizes smaller than $\mathrm{PM}_{2.5}$.

As motor vehicle emission standards become more stringent, basic data of particulate matter caused by traffic sources should be updated. In order to fill the data gap on the elemental composition and size-resolved distribution of particulate matter in the roadside environment in Tianjin, a DGI high-flow particle sampler was used to collect samples containing different sized particles from typical roads, including secondary road, major road, expressway and outer ring road. Ten kinds of heavy metal elements $(\mathrm{Cr}, \mathrm{Mn}, \mathrm{Co}, \mathrm{Ni}$, $\mathrm{Cu}, \mathrm{Zn}, \mathrm{Cd}, \mathrm{Sn}, \mathrm{Sb}$ and $\mathrm{Pb}$ ) were analyzed by the ICP-MS. The main objectives were as follows: (1) to determine the size-resolved concentration distribution of PM-bound heavy metal at road environment; (2) to assess the possible sources of the heavy metal elements; and (3) to accumulate research data on the characteristics of urban road particulate matter caused by vehicle emissions and provide a scientific basis and recommendations for the control of pollution with traffic as the source.

\section{Materials and Methods}

\subsection{Sampling Location}

Tianjin is a city located in northern China. It is an international port and an eco-city. There are 1569 roads in urban areas of Tianjin, which consist of secondary roads, major roads, urban expressways and outer ring roads. Therefore, four roads characteristic of these road types were selected as the sampling sites for monitoring particulate matter and traffic flow in Tianjin (Table 1 and Figure 1). Baidi Road (BD) was selected to represent the secondary road. Baidi Road is a one-way, two lane road, and samples were collected from a lane with traffic moving from south to north. Residential housing, a school and shops were located on the sides of Baidi Road. The three other typical roads selected for this study were one-way, four lane roads. Fukang Road (FK) was selected to represent the major road. Jianyang Road (JY) was selected to represent the urban expressway. The samples were collected from a lane of Jianyang Road with traffic moving from south to north. Waihuan Road (WH) is an outer ring road, and samples were collected from a lane with traffic moving from southeast to northwest. There were no tall buildings on the sides of the outer ring road. A blank site (BL) was set on the top floor of the Tianjin Ecoenvironmental Testing Center during the sampling period. During the sampling period, the meteorological parameters (i.e., temperature, relative humidity, wind speed, wind direction) were measured hourly by the automatic weather station, which were shown in Table S1. The daily average temperature varied between $26^{\circ} \mathrm{C}$ to $31{ }^{\circ} \mathrm{C}$ and the average relative humidity varied between $53 \%$ to $71 \%$. The predominant wind direction was southwest wind (BD), north-east wind (FK), south-west wind (JY) and south wind (WH). The sampling site on the four roads were all in the downwind direction of vehicle emissions, which can ensure that the sampling results were more realistic.

The vehicle types of the four roads are shown in Table 1. It was found that gasoline vehicles were the main type on the four roads, accounting for $95.13-99.46 \%$. During the sampling period, there were almost no heavy-duty diesel vehicles driving on the secondary road and major road. The number of diesel vehicles on urban expressway and outer ring road was relatively large, accounting for $3.84 \%$ and $4.87 \%$, respectively. 
Table 1. Traffic flow data of sampled sites.

\begin{tabular}{|c|c|c|c|c|c|c|c|}
\hline \multirow{2}{*}{ Sampling Sites } & \multirow{2}{*}{ Lanes } & \multirow{2}{*}{ Traffic Direction } & \multirow{2}{*}{ Traffic Volume (veh/h) } & \multicolumn{3}{|c|}{ Speed $(\mathbf{k m} / \mathbf{h})$} & \multirow{2}{*}{ Time } \\
\hline & & & & Min & Max & Mean & \\
\hline Secondary road (BD) & 2 & south to north & 1092 (G 99.46\%, D 0.54\%) * & 5.0 & 53.0 & 32.8 & 9-12 July 2015 \\
\hline Major road (FK) & 4 & west to east & 2139 (G 98.34\%, D 1.66\%) * & 13.4 & 62.3 & 50.3 & 3-6 July 2015 \\
\hline Urban expressway (JY) & 4 & south to north & 3834 (G $96.16 \%$, D $3.84 \%)$ * & 42.9 & 82.3 & 62.8 & 16-19 July 2015 \\
\hline Waihuan Road (WH) & 4 & southeast to northwest & 1267 (G 95.13\%, D 4.87\%) * & 29.6 & 81.1 & 62.7 & 23-26 July 2015 \\
\hline
\end{tabular}

${ }^{*} \mathrm{G}$ is the percentage of gasoline vehicle, and $\mathrm{D}$ is the percentage of diesel vehicle.

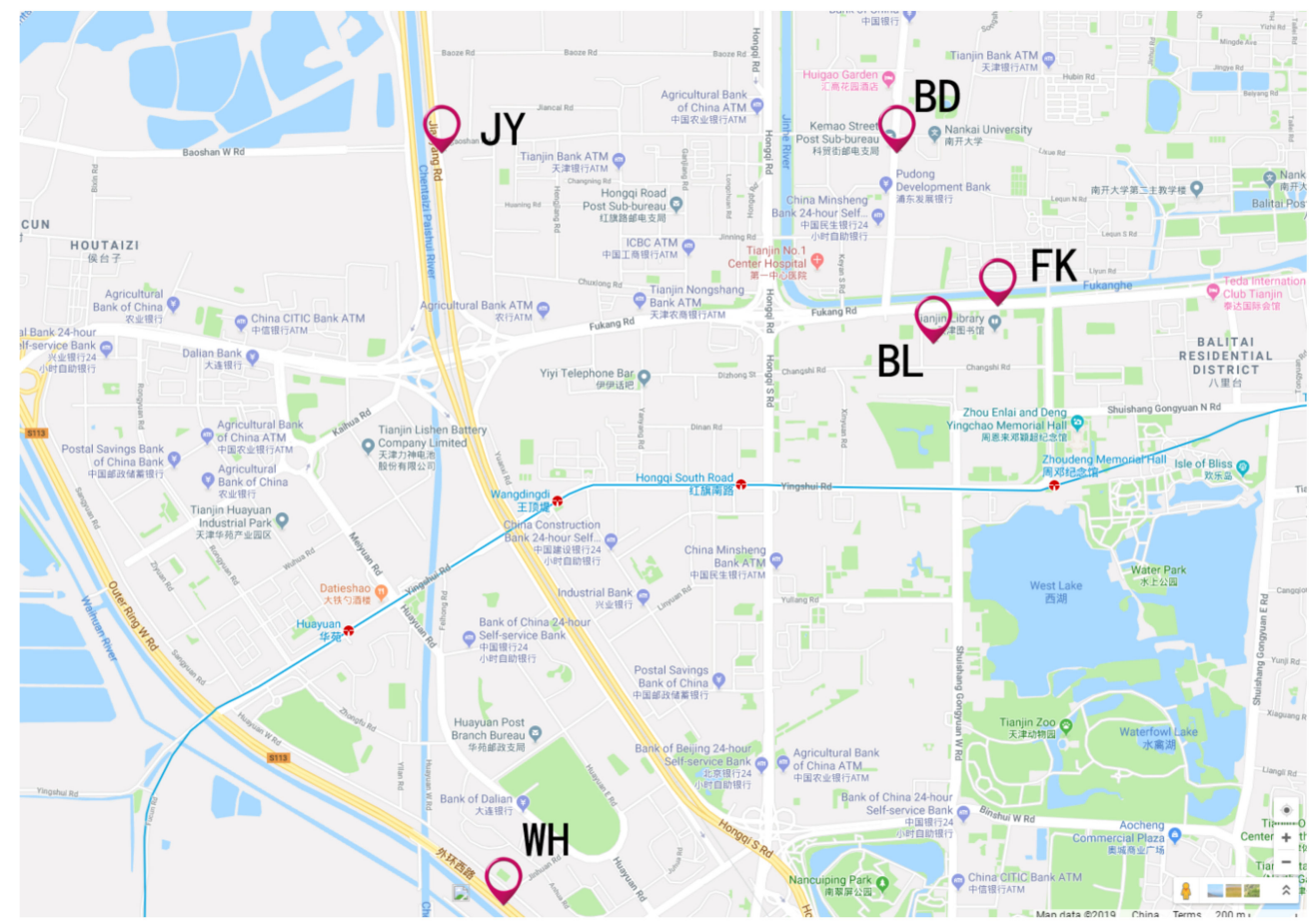

Figure 1. Location of sampling sites.

\subsection{Sampling and Analysis}

The sampling instruments were situated $2 \mathrm{~m}$ away from the closest traffic lane and $1.5 \mathrm{~m}$ above the ground. The particulate matter was collected continuously from the four sampling sites between 7:00 and 23:00 from Thursday to Sunday during July in 2015. A DGI multi-stage collision type particle sampler (Model 1570, Dekati, Kangasala, Finland) was used to collect the particulate matter [10]. The flow rate of the DGI sampler is $70 \mathrm{~L} / \mathrm{min}$. During flow calibration, we connected the flow calibration instrument to the DGI sampling inlet. After the instrument is stable, the flow calibration instrument was used to measure and repeat the measurement 3 times to ensure that the error is within $\pm 2 \%$. The DGI sampler was evaluated pre and post-sampling to ensure the consistency of sampling flow rate. The DGI sampler was used at each stage of the DGI sampler to collect four fractions containing particles with sizes of $<0.2 \mu \mathrm{m}$ (size fraction I), $0.2-0.5 \mu \mathrm{m}$ (size fraction II), $0.5-1.0 \mu \mathrm{m}$ (size fraction III) and 1.0-2.5 $\mu \mathrm{m}$ (size fraction IV). A Teflon filter was used for sampling ( $47 \mathrm{~mm}$, pore size of $5 \mu \mathrm{m}$, Millipore Corp., Saint Louis, USA). The samples obtained by the Teflon filter were used to determine the particulate matter mass and to analyze the heavy metal elements. Microwave digestion instrument (MDS-6G, Sineo, Shanghai, China) was used to process samples The Teflon filter. Inductively coupled plasma mass spectrometry (ICP-MS, Agilent 7500A, Agilent, Santa Clara, USA) was used for the elemental analysis, in which thirteen heavy metal elements present in the filters were analyzed and included Ti, $\mathrm{Cr}, \mathrm{Mn}, \mathrm{Co}, \mathrm{Ni}, \mathrm{Cu}, \mathrm{Zn}, \mathrm{Cd}, \mathrm{Sn}, \mathrm{Sb}$ and $\mathrm{Pb}$. The methods used for sample pretreatment and analysis of the heavy metal elements are detailed in the literature [11]. 


\subsection{Evaluation Model}

\subsubsection{Enrichment Factor (EF)}

The enrichment factor of heavy metals can be used to evaluate the extent to which the concentration of heavy metals exceeds that of the background and to determine whether the pollution is caused by natural and anthropogenic sources [12-14]. The formula used to calculate the EF is as follows:

$$
\mathrm{EF}=\frac{\left(C_{i} / C_{r e f}\right)_{\mathrm{PM}}}{\left(C_{i} / C_{r e f}\right)_{\mathrm{UCC}}}
$$

where $C_{n}$ and $C_{r e f}$ were the concentrations of the target element and the reference element in the sample (PM) and the upper continental crust (UCC), respectively. Ti and Si were typically used as reference elements [15]. In this study, Ti was selected as the reference element and the average element concentrations of UCC were obtained from Wei's report [16]. The EF value was interpreted using the categorization shown in Table 2.

Table 2. Enrichment factor (EF) categorization.

\begin{tabular}{cc}
\hline EF Value & Enrichment Level \\
\hline $\mathrm{EF}<3$ & Minor \\
$3<\mathrm{EF}<5$ & Moderate \\
$5<\mathrm{EF}<10$ & Moderately severe \\
$10<\mathrm{EF}<25$ & Severe \\
$25<\mathrm{EF}<50$ & Very severe \\
$\mathrm{EF}>50$ & Extremely severe \\
\hline
\end{tabular}

\subsubsection{Principal Component Analysis (PCA)}

Principal Component Analysis (PCA) is a kind of factor analysis that simplifies the reduction of data from complex relationships between variables [17-19]. There is a strong correlation between the chemical components of particulate matter originating from the same source of pollution. The goal of PCA is based on the interrelationship between different chemical components in the particle. The number of factors is screened and quantified among the many variables, and the load of each factor is calculated. These factors can be used to explain the majority of the changes in the analyzed elements from a large number of samples. Furthermore, the pollution sources that contribute to the chemical composition of the particulate matter are identified and analyzed. The PCA method was used to determine the source of the heavy metals in the particulate matter samples (which includes fractions I, II, III and IV) that were collected from the various roadside environments during the sampling period. First, the data obtained for each component of the PM were Z-score normalized using the conversion formula. Then, the metal components were described by several main factors using the maximum rotation method of variance, and the characteristic values of each factor were extracted. The higher the load value of the factor, the greater the representativeness.

\subsection{Quality Assurance and Control}

The filter used in the experiment was equilibrated in a constant temperature and humidity balance chamber for $48 \mathrm{~h}$. When the filter was weighed, an electrostatic removal device was used to avoid interference. The analysis of a blank sample, a standard sample and a duplicate sample were required after every 10 samples for the elemental detection and analysis. All the glass vessels were soaked in dilute nitric acid for $24 \mathrm{~h}$ and rinsed with Milli-Q water. The relative standard deviation (RSD) of the data obtained for the duplicate samples is $<5.6 \%$. The regression coefficient of the calibration curves obtained for the various heavy metals is $>0.999$. The data were analyzed and processed using the statistical analysis software EXCEL 2019 (Microsoft Corporation) and SPSS 22.0 (IBM Corporation). 


\section{Results and Discussion}

\subsection{Concentrations of PM-Bound Heavy Metals}

The concentrations of the PM-bound heavy metal in the samples collected from the four road environments in Tianjin are shown in Figure 2. The 10 elements evaluated in this study were all trace heavy metal elements. The total concentrations of these 10 heavy metal elements in the $\mathrm{PM}_{2.5}$ samples collected from the $\mathrm{BD}, \mathrm{FK}$, JY and $\mathrm{WH}$ sites were $597 \pm 251 \mathrm{ng} / \mathrm{m}^{3}, 546 \pm 316 \mathrm{ng} / \mathrm{m}^{3}, 518 \pm 310 \mathrm{ng} / \mathrm{m}^{3}$ and $640 \pm 237 \mathrm{ng} / \mathrm{m}^{3}$, respectively. The ratios of the heavy metal element concentrations compared to the $\mathrm{PM}_{2.5}$ concentration in the samples collected from each sampling site were $0.30 \%$ (BD), $0.35 \%$ (FK), $0.30 \%$ (JY) and $0.33 \%(\mathrm{WH})$. Overall, the concentrations of $\mathrm{Zn}$ and $\mathrm{Mn}$ were the highest, and the concentrations of $\mathrm{Co}, \mathrm{Cd}, \mathrm{Sn}$ and $\mathrm{Sb}$ were the lowest. The concentrations of the elements found in the samples collected from each sampling site were different. The higher concentrations of $\mathrm{Zn}, \mathrm{Pb}, \mathrm{Cu}$ and $\mathrm{Sb}$ found in the samples collected from the secondary road (BD) may be caused by the longer congestion time (low vehicle speed and multiple traffic lights), which indicated that the secondary roadside environment was more susceptible to pollution from motor vehicle emissions.

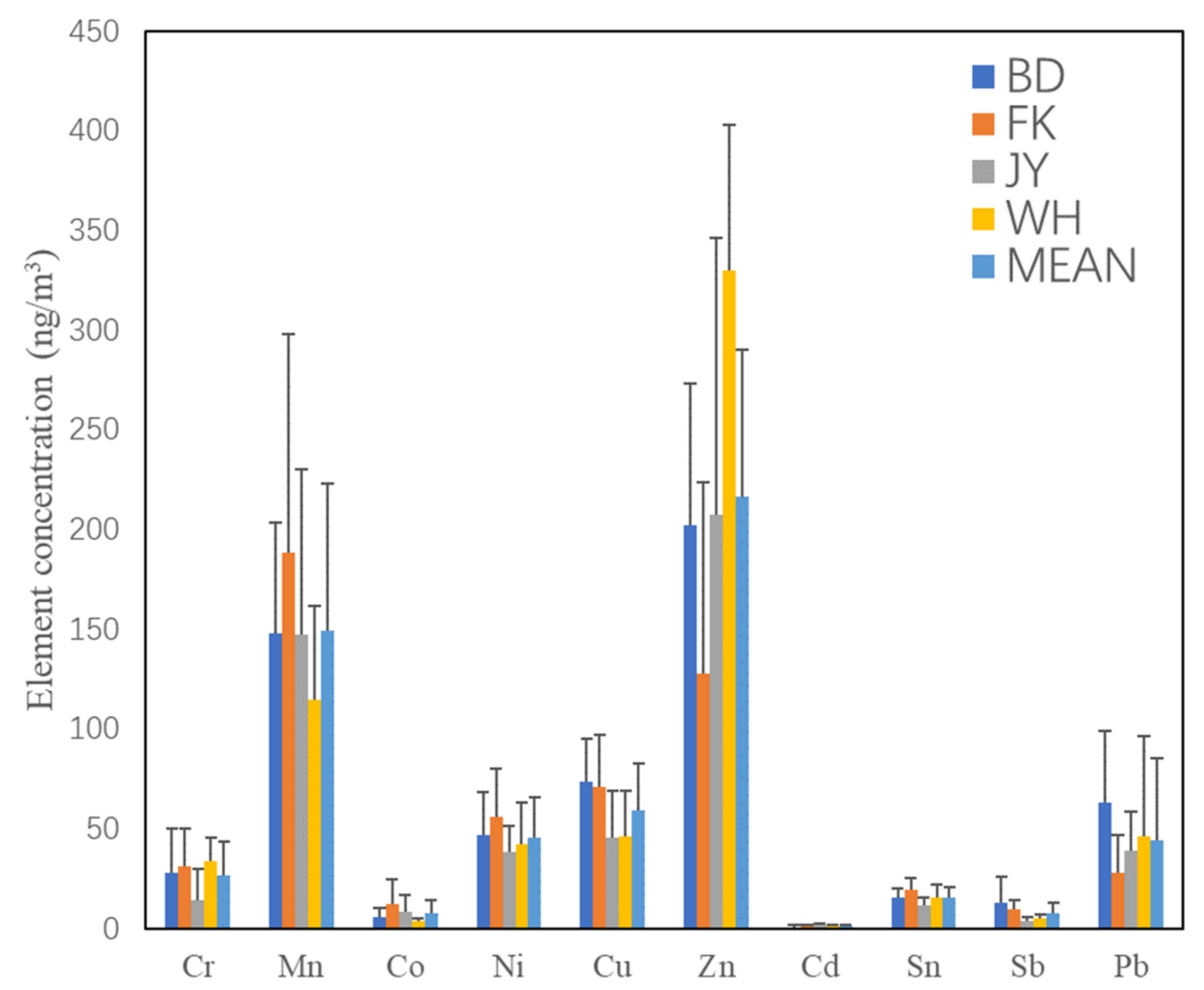

Figure 2. Concentrations of the heavy metal elements measured in the samples collected at the four road environment sampling sites in Tianjin.

Table 3 showed the comparison of the amounts of some elements found in the $\mathrm{PM}_{2.5}$ samples collected in this study to that of those collected in other regions. The mass concentrations of $\mathrm{Zn}, \mathrm{Pb}, \mathrm{Sb}$ and $\mathrm{Sn}$ obtained in this study were lower than those measured in Beijing [20], Hong Kong [9], Macao [21] and Kolkata [22]. The samples obtained in this study were collected after new motor vehicle standards (China V) and fuel quality requirements (China V) were implemented in Tianjin, indicating that the implementation and improvement of the vehicle standards and fuel quality requirements had a greater impact on vehicle emissions. In addition, the mass concentrations of $\mathrm{Mn}$ and Ni obtained in this study were higher than those measured in Beijing, Hong Kong and Macao, indicating that these elements were affected by motor vehicle emissions and other anthropogenic pollution sources. 
Table 3. Concentration of heavy metal elements in the $\mathrm{PM}_{2.5}$ samples obtained from different regions $\left(\mathrm{ng} / \mathrm{m}^{3}\right)$.

\begin{tabular}{cccccc}
\hline & This Study & Beijing [20] & Hong Kong [9] & Macao [21] & Kolkata [22] \\
\hline $\mathrm{Cr}$ & $27 \pm 17$ & - & - & - & 84 \\
$\mathrm{Mn}$ & $150 \pm 74$ & 46 & 31 & 11 & 132 \\
$\mathrm{Co}$ & $8 \pm 7$ & - & - & - & 2.1 \\
$\mathrm{Ni}$ & $46 \pm 20$ & - & 5.8 & 22 & 40 \\
$\mathrm{Cu}$ & $59 \pm 23$ & 33 & 300 & 34 & 58 \\
$\mathrm{Zn}$ & $217 \pm 73$ & 399 & - & 593 & 542 \\
$\mathrm{Cd}$ & $1.5 \pm 0.6$ & - & 29 & - & 5 \\
$\mathrm{Sn}$ & $16 \pm 5$ & - & 41 & - & 16 \\
$\mathrm{Sb}$ & $8 \pm 5$ & - & 61 & 274 & 8.7 \\
$\mathrm{~Pb}$ & $44 \pm 41$ & 163 & & & 368 \\
\hline
\end{tabular}

\subsection{Size-Resolved Concentration of Heavy Metal Elements}

The size-resolved concentration of heavy metal elements, obtained from the four roadside environment sampling sites, were shown in Figure 3. There were differences in the concentration of most heavy metal elements for the various size fractions. The concentrations of $\mathrm{Cu}, \mathrm{Zn}, \mathrm{Cd}, \mathrm{Sn}$ and $\mathrm{Pb}$ were the highest in size fraction III $(0.5-1.0 \mu \mathrm{m})$ and size fraction IV $(1.0-2.5 \mu \mathrm{m})$. Cd, $\mathrm{Cu}, \mathrm{Zn}$ and $\mathrm{Pb}$ were the elements that indicate emissions from tire wear. $\mathrm{Cu}, \mathrm{Pb}$ and $\mathrm{Zn}$ were the elements that indicate emissions from brake pad wear. The concentrations of these elements were the highest in the larger particle size fractions. In addition, $\mathrm{Sb}$ was usually added to brake pads in the form of $\mathrm{Sb}_{2} \mathrm{~S}_{3}$, which could account for $5-7 \%$ [23,24]. In this study, Sb was present in size fraction II $(0.2-0.5 \mu \mathrm{m})$ and size fraction III $(0.5-1.0 \mu \mathrm{m})$. The concentrations of $\mathrm{Cr}$, Co and $\mathrm{Ni}$ were the highest in size fraction I $(<0.2 \mu \mathrm{m})$ and size fraction II $(0.2-0.5 \mu \mathrm{m})$, indicating that the main source of $\mathrm{Cr}, \mathrm{Co}$ and Ni was motor vehicle exhaust. Due to the differences in the sampling device parameters and the material and loading effect of the sampling membrane, the particle size distribution may vary in different research studies. Therefore, it was difficult to compare the results obtained using different particle size distribution studies. Overall, the sizeresolved concentrations of heavy metal elements measured in this study were similar to those measured in Beijing [25].

\subsection{Source Identification of Heavy Metal Elements}

\subsubsection{Enrichment Factor}

Enrichment factor (EF) is used to determine whether the element is affected by the anthropogenic source. The EFs of heavy metal elements in the particulate matter in the typical road environment are shown in Figure 4. The results show that EFs of $\mathrm{Cr}$ and Mn are less than 10, which was almost no enrichment in the roadside environment. The Mn element is less polluted in the roadside and the anthropogenic source is not the dominant factor. 

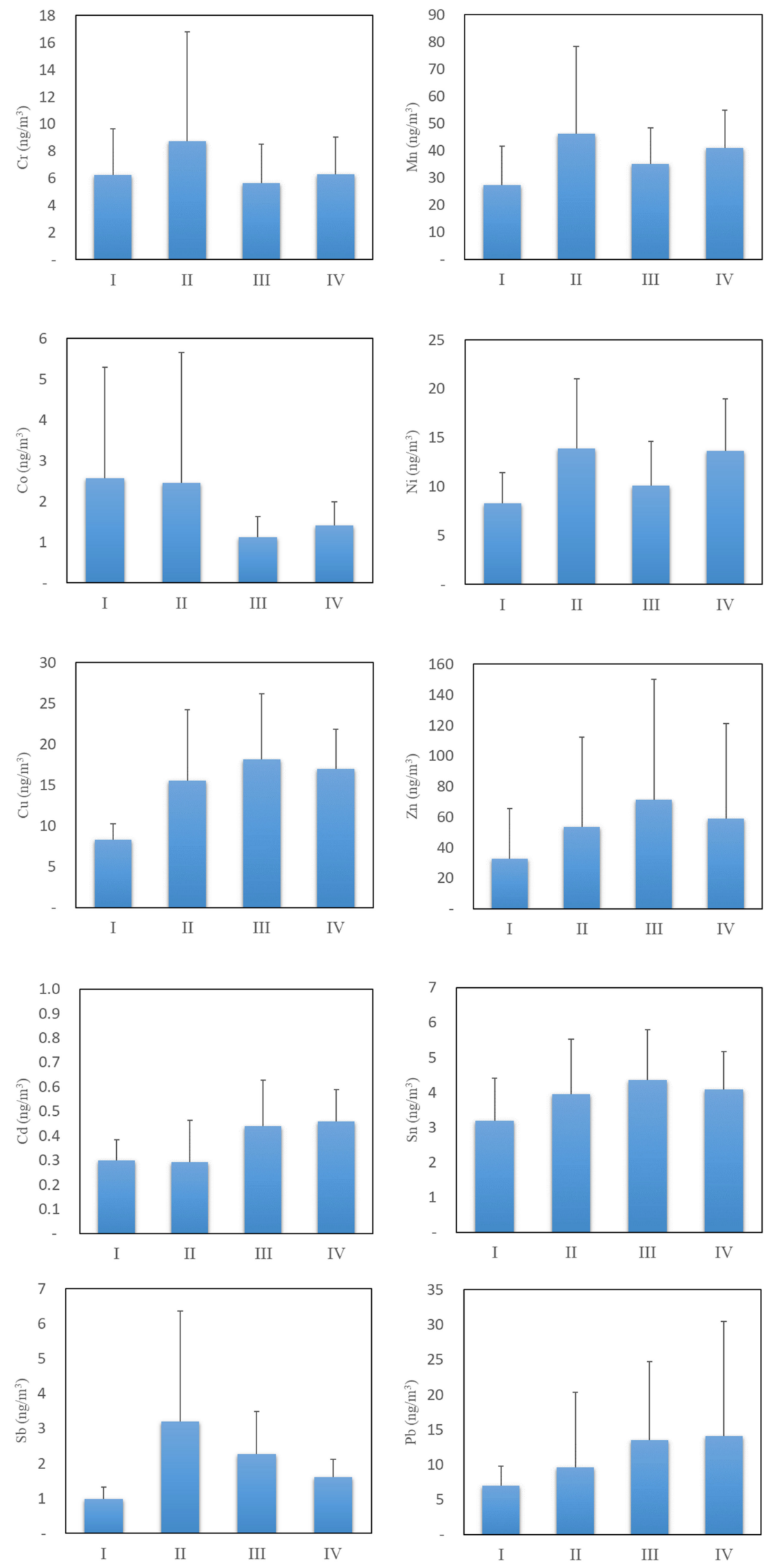

Figure 3. Size-resolved concentration of heavy metal elements in particulate matter. 


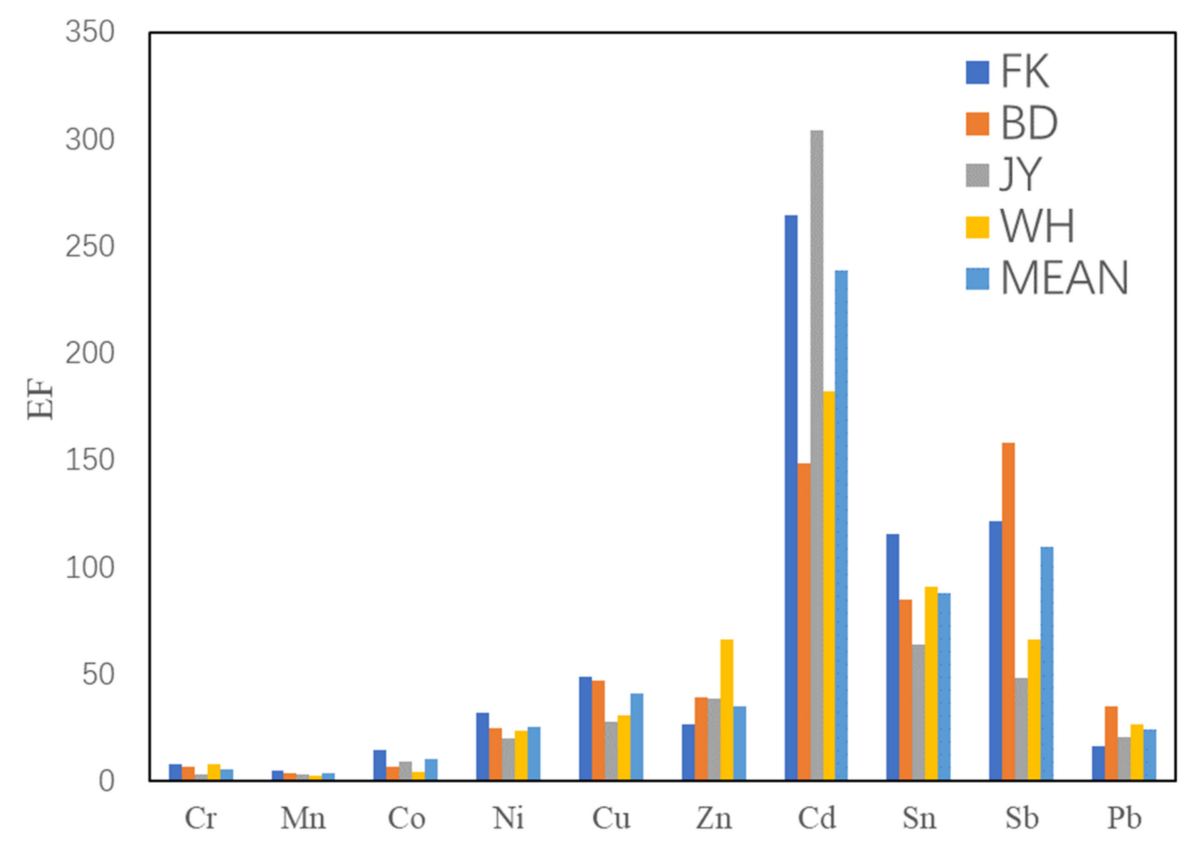

Figure 4. Enrichment factors of metals in $\mathrm{PM}_{2.5}$ at roadside.

The EF values higher than $10(\mathrm{Co}, \mathrm{Cd}, \mathrm{Cu}, \mathrm{Ni}, \mathrm{Pb}, \mathrm{Sn}, \mathrm{Sb}$ and $\mathrm{Zn})$ are highly enriched in the roadside environment, which are obviously related to the emission of anthropogenic pollution sources. $\mathrm{Cd}, \mathrm{Cu}$ and $\mathrm{Pb}$ are positively correlated with vehicle exhaust emissions. $\mathrm{Sb}$ and $\mathrm{Sn}$ are mainly found in brake pads $[26,27] . \mathrm{Zn}$ is the main component of catalyst for the rubber tire manufacturing process [28].

\subsubsection{PCA}

The PCA factors were identified using the maximum variance rotation, and the resulting factor load matrix was shown in Table 4 . A factor score of 0.5 was usually selected as the lowest significance level. The results showed that the accumulative interpretation variances of the four size fractions, $\mathrm{PM}_{0.2}, \mathrm{PM}_{0.2-0.5}, \mathrm{PM}_{0.5-1.0}$ and $\mathrm{PM}_{1.0-2.5}$, reached $80.29 \%$, $79.56 \%, 79.57 \%$ and $71.42 \%$, respectively, which better preserved the information of the original data.

Table 4. Maximum variance rotation factor analysis of PM.

\begin{tabular}{|c|c|c|c|c|c|c|c|c|c|c|}
\hline \multirow[t]{2}{*}{ Element } & \multicolumn{2}{|c|}{$\mathrm{PM}_{0.2}$} & \multicolumn{3}{|c|}{$\mathrm{PM}_{0.2-0.5}$} & \multicolumn{3}{|c|}{$\mathrm{PM}_{0.5-1.0}$} & \multicolumn{2}{|c|}{$\mathrm{PM}_{1,0-2.5}$} \\
\hline & F1 & F2 & F1 & F2 & F3 & F1 & F2 & F3 & F1 & F2 \\
\hline $\mathrm{Cr}$ & 0.826 & & 0.629 & & & 0.509 & & & 0.803 & \\
\hline $\mathrm{Mn}$ & 0.950 & & 0.878 & & & 0.956 & & & 0.945 & \\
\hline Co & 0.971 & & 0.875 & & & 0.943 & & & 0.871 & \\
\hline $\mathrm{Ni}$ & 0.963 & & 0.860 & & & 0.874 & & & 0.914 & \\
\hline $\mathrm{Cu}$ & 0.629 & & 0.565 & 0.733 & & & 0.879 & & 0.850 & \\
\hline $\mathrm{Zn}$ & & 0.878 & & 0.542 & 0.513 & & & 0.553 & & 0.716 \\
\hline $\mathrm{Cd}$ & & 0.932 & & & 0.936 & & & 0.937 & & 0.747 \\
\hline Sn & 0.926 & & & 0.853 & & & 0.959 & & 0.777 & \\
\hline $\mathrm{Sb}$ & 0.713 & & & 0.813 & & & 0.751 & & & \\
\hline $\mathrm{Pb}$ & & 0.923 & & & 0.911 & & & 0.907 & & 0.869 \\
\hline$\%$ of variance & 55.01 & 25.28 & 43.44 & 18.71 & 17.41 & 36.85 & 23.39 & 19.33 & 50.99 & 20.43 \\
\hline Accumulative $\%$ & 55.01 & 80.29 & 43.44 & 62.15 & 79.56 & 36.85 & 60.24 & 79.57 & 50.99 & 71.42 \\
\hline Source & VE and BW & TW & VE & BW & TW & VE & BW & TW & $\mathrm{VE}$ and $\mathrm{BW}$ & TW \\
\hline
\end{tabular}

In $\mathrm{PM}_{0.2}$ and $\mathrm{PM}_{1.0-2.5}$, the initial interpretation variances of factor 1 were $55.01 \%$ and $50.99 \%$, respectively. $\mathrm{Cr}, \mathrm{Co}, \mathrm{Ni}, \mathrm{Cu}, \mathrm{Sn}$ and $\mathrm{Sb}$ were found to have the highest loading coefficients. Accordingly, the presence of $\mathrm{Ni}, \mathrm{Cr}$ and $\mathrm{Co}$ could be caused by the combustion of fossil fuels and transportation [29-31]. In addition, $\mathrm{Zn}, \mathrm{Sb}, \mathrm{Sn}, \mathrm{Cd}$ and $\mathrm{Mn}$ 
were characteristic of non-exhaust emissions [32,33]. Sb was mainly from brake pad wear in motor vehicles. Therefore, the factor 1 of $\mathrm{PM}_{0.2}$ and $\mathrm{PM}_{1.0-2.5}$ could be interpreted as vehicle exhaust (VE) and brake pad wear sources (BW). The loading factor of $\mathrm{Zn}, \mathrm{Cd}$ and $\mathrm{Pb}$ in factor 2 was higher in $\mathrm{PM}_{0.2}$ and $\mathrm{PM}_{1.0-2.5}$. $\mathrm{Zn}, \mathrm{Cu}$ and $\mathrm{Cd}$ were often indicators of pollution caused by vehicle tires wear [34-36]. Because of the increased use of unleaded gasoline, vehicle exhaust was no longer the main source of $\mathrm{Pb}$. $\mathrm{Pb}$ might be mainly originating from the vehicle mechanical wear (such as tire wear). Therefore, the factor 2 of $\mathrm{PM}_{0.2}$ and $\mathrm{PM}_{1.0-2.5}$ could be interpreted as the tire wear source (TW).

In $\mathrm{PM}_{0.2-0.5}$ and $\mathrm{PM}_{0.5-1.0}$, the PCA results were different from other particle sizes. These factors included about $79.56 \%\left(\mathrm{PM}_{0.2-0.5}\right)$ and $79.57 \%\left(\mathrm{PM}_{0.5-1.0}\right)$ of total variance. Factor 1 was related to $\mathrm{Cr}, \mathrm{Mn}, \mathrm{Co}$ and $\mathrm{Ni}$ included $43.44 \%\left(\mathrm{PM}_{0.2-0.5}\right)$ and $36.85 \%\left(\mathrm{PM}_{0.5-1.0}\right)$ of total variance, indicating the main source of vehicle exhaust (VE). Factor 2 was related to brake pad wear (BW) in these size fractions, which could be one of the main sources of metals such as $\mathrm{Cu}, \mathrm{Zn}, \mathrm{Sb}$ and $\mathrm{Sn}$. Factor 3 was related to $\mathrm{Zn}, \mathrm{Cd}$ and $\mathrm{Pb}$ which could be caused by tire wear (TW). Therefore, it could be seen that vehicle exhaust (VE), brake pad wear (BW) and tire wear (TW) were regarded as the three main sources of particulate matter at roadside environments.

\section{Conclusions}

The concentration of heavy metal elements in the PM samples collected from four roadside environment sampling sites, $\mathrm{BD}, \mathrm{FK}, \mathrm{JY}$ and $\mathrm{WH}$, were $597 \pm 251 \mathrm{ng} / \mathrm{m}^{3}$, $546 \pm 316 \mathrm{ng} / \mathrm{m}^{3}, 518 \pm 310 \mathrm{ng} / \mathrm{m}^{3}$ and $640 \pm 237 \mathrm{ng} / \mathrm{m}^{3}$, respectively. The concentrations of heavy metal elements found in the samples collected from various roads were different. $\mathrm{Cd}, \mathrm{Cu}, \mathrm{Zn}$ and $\mathrm{Pb}$ were the elements that indicated emissions from tire wear, and $\mathrm{Cu}, \mathrm{Pb}$ and $\mathrm{Zn}$ were the elements that indicated emissions from brake pad wear. The concentrations of these elements were the highest in the larger particle size fractions. Based on the source identification results, there were differences in the analysis results obtained for particles with different particle sizes. PCA revealed the various source of heavy metals including vehicle exhaust, brake pad wear and tire wear at roadside environments. Concerning the population of new energy vehicles increasing in the future, exhaust emissions will be significantly reduced. While the brake pad wear and tire wear will probably be the main source of heavy metals at roadside. Therefore, it is necessary to strengthen the research on the prevention and control of PM from non-exhaust sources of vehicles.

Supplementary Materials: The following are available online at https:/ / www.mdpi.com/article/10.3 390/atmos12091130/s1, Table S1. Meteorological parameters during sampling.

Author Contributions: Q.Z.: Conceptualization, Methodology, Writing-Original draft preparation, Writing-Review and Editing. Y.Z.: Validation. L.W.: Supervision. H.M.: Funding acquisition, Methodology, Writing-Review and Editing. All authors have read and agreed to the published version of the manuscript.

Funding: This work was supported by the Tianjin Science and Technology Plan Project (19YFZCSF00960, 20YFZCSN01000), Tianjin Education Commission Research Project (2017KJ053) and The Fundamental Research Funds for the Central University (63211075).

Institutional Review Board Statement: Not applicable.

Informed Consent Statement: Not applicable.

Data Availability Statement: The data presented in this study are available on request from the corresponding author.

Conflicts of Interest: The authors declare no conflict of interest.

\section{References}

1. MEE. China Vehicle Environmental Management Annual Report (2018); Ministry of Ecology and Environment of the People's Republic of China: Beijing, China, 2018. 
2. He, J.; Wu, L.; Mao, H.; Liu, H.; Jing, B.; Yu, Y.; Ren, P.; Feng, C.; Liu, X. Development of a vehicle emission inventory with high temporal-spatial resolution based on NRT traffic data and its impact on air pollution in Beijing-Part 2: Impact of vehicle emission on urban air quality. Atmos. Chem. Phys. 2016, 16, 3171-3184. [CrossRef]

3. Jing, B.; Wu, L.; Mao, H.; Gong, S.; He, J.; Zou, C.; Song, G.; Li, X.; Wu, Z. Development of a vehicle emission inventory with high temporal-spatial resolution based on NRT traffic data and its impact on air pollution in Beijing-Part 1: Development and evaluation of vehicle emission inventory. Atmos. Chem. Phys. 2016, 16, 3161-3170. [CrossRef]

4. Song, C.; Ma, C.; Zhang, Y.; Wang, T.; Wu, L.; Wang, P.; Liu, Y.; Li, Q.; Zhang, J.; Dai, Q.; et al. Heavy-duty diesel vehicles dominate vehicle emissions in a tunnel study in northern China. Sci. Total Environ. 2018, 637, 431-442. [CrossRef] [PubMed]

5. Zhang, Q.; Wu, L.; Fang, X.; Liu, M.; Zhang, J.; Shao, M.; Lu, S.; Mao, H. Emission factors of volatile organic compounds (VOCs) based on the detailed vehicle classification in a tunnel study. Sci. Total Environ. 2018, 624, 878-886. [CrossRef] [PubMed]

6. Zhang, Q.; Wu, L.; Yang, Z.; Zou, C.; Liu, X.; Zhang, K.; Mao, H. Characteristics of gaseous and particulate pollutants exhaust from logistics transportation vehicle on real-world conditions. Transp. Res. Part D Transp. Environ. 2016, 43, 40-48. [CrossRef]

7. Allen, A.G.; Nemitz, E.; Shi, J.P.; Harrison, R.M.; Greenwood, J.C. Size distributions of trace metals in atmospheric aerosols in the United Kingdom. Atmos. Environ. 2001, 35, 4581-4591. [CrossRef]

8. Malandrino, M.; Casazza, M.; Abollino, O.; Minero, C.; Maurino, V. Size resolved metal distribution in the PM matter of the city of Turin (Italy). Chemosphere 2016, 147, 477-489. [CrossRef] [PubMed]

9. Cheng, Y.; Lee, S.; Gu, Z.; Ho, K.; Zhang, Y.; Huang, Y.; Chow, J.C. PM2.5 and PM10-2.5 chemical composition and source apportionment near a Hong Kong roadway. Particuology 2015, 18, 96-104. [CrossRef]

10. Happo, M.S.; Uski, O.; Jalava, P.I.; Kelz, J.; Brunner, T.; Hakulinen, P.; Mäki-Paakkanen, J.; Kosma, V.M.; Jokiniemi, J.; Obernberger, I. Pulmonary inflammation and tissue damage in the mouse lung after exposure to PM samples from biomass heating appliances of old and modern technologies. Sci. Total Environ. 2013, 443, 256-266. [CrossRef]

11. Zhang, Q.-J.; Wu, L.; Zhang, Y.-J.; Fang, X.-Z.; Mao, H.-J.; Wu, L.-P. Characteristics and health risk assessment of heavy metal in PM2.5 in tunnel environment. China Environ. Sci. 2018, 38, 4706-4712.

12. Galindo, N.; Yubero, E.; Nicolas, J.F.; Varea, M.; Crespo, J. Characterization of metals in PM1 and PM10 and health risk evaluation at an urban site in the western Mediterranean. Chemosphere 2018, 201, 243-250. [CrossRef]

13. Wang, J.; Pan, Y.; Tian, S.; Chen, X.; Wang, L.; Wang, Y. Size distributions and health risks of particulate trace elements in rural areas in northeastern China. Atmos. Res. 2016, 168, 191-204. [CrossRef]

14. Mohsen, M.; Ahmed, M.B.; Zhou, J.L. Particulate matter concentrations and heavy metal contamination levels in the railway transport system of Sydney, Australia. Transp. Res. Part D Transp. Environ. 2018, 62, 112-124. [CrossRef]

15. Duan, J.; Tan, J.; Wang, S.; Hao, J.; Chai, F. Size distributions and sources of elements in particulate matter at curbside, urban and rural sites in Beijing. J. Environ. Sci. 2012, 24, 87-94. [CrossRef]

16. Wei, F. Background value of soil environment in China. Environ. Sci. 1991, 12, 12-19.

17. Romanazzi, V.; Casazza, M.; Malandrino, M.; Maurino, V.; Piano, A.; Schilirò, T.; Gilli, G. PM10 size distribution of metals and environmental-sanitary risk analysis in the city of Torino. Chemosphere 2014, 112, 210-216. [CrossRef]

18. Soleimani, M.; Amini, N.; Sadeghian, B.; Wang, D.; Fang, L. Heavy metals and their source identification in particulate matter (PM2. 5) in Isfahan City, Iran. J. Environ. Sci. 2018, 72, 166-175. [CrossRef]

19. Talbi, A.; Kerchich, Y.; Kerbachi, R.; Boughedaoui, M. Assessment of annual air pollution levels with PM1, PM2.5, PM10 and associated heavy metals in Algiers, Algeria. Environ. Pollut. 2018, 232, 252-263. [CrossRef]

20. Song, S.; Wu, Y.; Jiang, J.; Yang, L.; Hao, J. Characteristics of elements in size-resolved fine particles in a typical road traffic environment in Beijing. Acta Sci. Circumstantiae 2012, 32, 66-73.

21. Wu, Y.; Hao, J.; Fu, L.; Hu, J.; Wang, Z.; Tang, U. Chemical characteristics of airborne particulate matter near major roads and at background locations in Macao, China. Sci. Total Environ. 2003, 317, 159-172. [CrossRef]

22. Das, R.; Khezri, B.; Srivastava, B.; Datta, S.; Sikdar, P.K.; Webster, R.D.; Wang, X. Trace element composition of PM 2.5 and PM 10 from Kolkata-A heavily polluted Indian metropolis. Atmos. Pollut. Res. 2015, 6, 742-750. [CrossRef]

23. Garg, B.D.; Cadle, S.H.; Mulawa, P.A.; Groblicki, P.J. Brake Wear Particulate Matter Emissions. Environ. Sci. Technol. 2000, 34 , 4463-4469. [CrossRef]

24. Sanders, P.G.; Xu, N.; Dalka, T.M.; Maricq, M.M. Airborne Brake Wear Debris: Size Distributions, Composition, and a Comparison of Dynamometer and Vehicle Tests. Environ. Sci. Technol. 2003, 37, 4060-4069. [CrossRef]

25. Song, S.; Wu, Y.; Jiang, J.; Yang, L.; Cheng, Y.; Hao, J. Chemical characteristics of size-resolved PM2.5 at a roadside environment in Beijing, China. Environ. Pollut. 2012, 161, 215-221. [CrossRef]

26. Harrison, R.M.; Jones, A.M.; Gietl, J.K.; Yin, J.; Green, D.C. Estimation of the contributions of brake dust, tire wear, and resuspension to nonexhaust traffic particles derived from atmospheric measurements. Environ. Sci. Technol. 2012, 46, 6523-6529. [CrossRef]

27. Limited, K.M.; Kennedy, P.; Gadd, J. Preliminary Examination of Trace Elements in Tyres, Brake Pads and Road Bitumen in New Zealand; Ministry of Transport: Wellington, New Zealand.

28. Dallosto, M.; Beddows, D.C.S.; Gietl, J.K.; Olatunbosun, O.; Yang, X.; Harrison, R.M. Characteristics of tyre dust in polluted air: Studies by single particle mass spectrometry (ATOFMS). Atmos. Environ. 2014, 94, 224-230. [CrossRef]

29. Pant, P.; Harrison, R.M. Estimation of the contribution of road traffic emissions to particulate matter concentrations from field measurements: A review. Atmos. Environ. 2013, 77, 78-97. [CrossRef] 
30. Querol, X.; Viana, M.; Alastuey, A.; Amato, F.; Moreno, T.; Castillo, S.; Pey, J.; Rosa, J.D.L.; Campa, A.S.D.L.; Artíñano, B. Source origin of trace elements in PM from regional background, urban and industrial sites of Spain. Atmos. Environ. 2007, 41, 7219-7231. [CrossRef]

31. Al-Momani, I.F. Trace elements in atmospheric precipitation at Northern Jordan measured by ICP-MS: Acidity and possible sources. Atmos. Environ. 2003, 37, 4507-4515. [CrossRef]

32. Li, F.-H.; Zhang, Y.-J.; Zhang, J.; Yuan, Y.; Wu, L.; Mao, H.-J. Characteristics of Particulate and Inorganic Elements of Motor Vehicles Based on a Tunnel Environment. Huanjing Kexue 2018, 39, 1014-1022. [CrossRef]

33. Thorpe, A.; Harrison, R.M. Sources and properties of non-exhaust particulate matter from road traffic: A review. Sci. Total Environ. 2008, 400, 270-282. [CrossRef] [PubMed]

34. Adamiec, E.; Jarosz-Krzemińska, E.; Wieszała, R. Heavy metals from non-exhaust vehicle emissions in urban and motorway road dusts. Environ. Monit. Assess. 2016, 188, 1-11. [CrossRef]

35. Apeagyei, E.; Bank, M.S.; Spengler, J.D. Distribution of heavy metals in road dust along an urban-rural gradient in Massachusetts. Atmos. Environ. 2011, 45, 2310-2323. [CrossRef]

36. Wang, C.-H.; Yan, K.; Han, X.-Y.; Shi, Z.; Bi, L.-M.; Xiang, F.; Ning, P.; Shi, J.-W. Physico-chemical Characteristic Analysis of PM2.5 in the Highway Tunnel in the Plateau City of Kunming. Huanjing Kexue 2017, 38, 4968-4975. [CrossRef] [PubMed] 